The first attempt to consider the Pearl Harbor dilemma in the framework of probability theory was done by the author in (Ambartzunian 2009: 8-16). The absence of any reaction to (Ambartzunian 2009: 8-16) on behalf of historians has prompted the author to look for less formal approaches. Now the purpose is to approach the particular historical event

[D7] $=$ on Dec. 7, 1941 the Japanese plane attacked Pearl Harbor,

in a way not depending on the mathematical constructions of (Ambartzunian 2009: 8-16). The term "Sextet" should remind about associations in astrophysics (famous Seyfert Sextet, a group of six galaxes closely packed in the space), but the approach is purely logical and combinatorial. In fact we consider [D7] as a member of a group of six historical events closely packed in time, and their joint inspection reveals rather unexpected aspects.

The main factual basis is the documental evidence contained in the Nobel Prise winner book THE SECOND WORLD WAR by WINSTON CHURCHILL, in particular in the cahapters PEARL HARBOUR! , JAPAN and CLOSER CONTACTS WITH RUSSIA. The article starts with a section

"Dice Allegory" that inspects [D7] jointly with the events

[D8-1] = on Dec. 8, 1941: Churchill declares war on Japan and

[D8-2] = December 8, 1941: US Congress declares war on Japan.

Written in the form of a "dialog" imitating the famous style by Plato, the first section provides a self-sufficient motivation for putting probability questions about the mentioned historical events, as well as (in the next section) about the other members of the "Sextet", which are the events

[D5] = December 5, 1941 Britain declares war on on Finland, Hungary and

Romania, [D6] = December 6, 1941: Moscow offensive by the Red

Army ,

[D10] $=$ December 8-10, Japanese air offensive against the US bases on

Philippines, [D11] = Hitler declares of war on the USA.

A general note is in order: low estimate of the probability of an event does not directly imply that the event did not take place in the real history. Hence neither support nor refutation of [D7] is among the purposes of the present paper. We tacitly extend this principle as regards conclusions obtained in the sections that follow.

\title{
Dice Metaphor
}

Usually probabilistic questions are put as regards the future, as demonstrated by the respectable field of the actuarial sciences. So why we should at all start thinking about the probabilities of the events that belong to the past? After a Younger Collegue (YC) of the author, who was aware of the previous attempt (Ambartzunian 2009: 8-16), put exactly the same question a dialogue followed:

- Do you have a neighbour who is a backgammon addict? - I

asked. -(YC) - Yes, a pensioner, his name is Garabed, he plays

every day.

- What was the result of his first dice drop for yesterday? Was it du shesh, i.e. $(6,6)$ ?

-(YC) - Garabed rarely informs me on such details, only on the days of his greatest backgammon triumphs. But why is it important?

- Imagine that when you meet Garabed today, he says: "Yesterday during a game, I dropped du shesh k times in a row". What would you answer?

-(YC) - My answer would depend on the value of $k$. If $k=10$ say, then I would answer "Excuse me Garabed, I do not believe you, this is impossible".

- Strictly speaking, this will be an incorrect answer. The correct answer should sound: "Garabed,

I do not believe you, ten du shesh in a row has too small a probability. But if you really have triumphed that way, this would mean that with high probability you are a swindler". On the other hand, if Garabed discusses the question with his grand-child, the reaction can be: "Gran-dad, I always knew that you are the greatest backgammon player in the world". 
-(YC) - I appreciate the power of your remark.

- Now instead of backgammon think about World War II before December 7, 1941. What could be the optimal step for US to undertake to bring about the fastest victory over Berlin-RomeTokyo

Axis and their ultimate "unconditional surrender"?

-(YC) - What else but earliest possible start of a war on them?

- The US Congress was against unilateral declaration of a war on Germany. Probably, one of the reasons was the WWI experience, when the USA declared war on Germany when there was no direct aggression by Germany. Within the USA, that move was in fact so unpopular, that US military performance in that war was greatly reduced and the eventual peace imposed on Germany was not "unconditional surrender". This is why before [D7] the tripartite pact powers did

not demonstrate any aggressive intentions as regards the USA.

(YC) - It seems Roosevelt learned the WWI lesson: I recall that before Pearl Harbor, he announced many times that US will enter the European war only in answer to a direct aggression.

- Correct; but let me use a backgammon allegory. Can you tell me, does Garabed prefer to boast in advance or he prefers to glorify the dice? I explain,

to boast in advance: starting the game Garabed says "I am going to win in an extremal way (say will drop ten du shesh in a row)",

to glorify the dice: after winning the game Garabed says "The dice had accomplished what was impossible to expect in advance". dice.

(YC) -As a wise man, Garabed never boasts in advance. He prefers to glorify (or to curse) the

- In the USA only Congress is eligible to declare war. The famous Roosevelt's Infamy

Day

address to Congress on December 8, 1941 reminds me Garabed glorifying the dice: the dice of history sent an unexpected chance to enable Congress to declare war on Japan.

(YC) - I would agree that the allegory is valid, if

$\mathrm{P}=$ the probability that Japan undertook [D7] was sufficiently small.

- The whole problem is indeed about the value of the probability $\mathrm{P}$ in question. But look what

US Secretary of the Navy Knox reported to Roosevelt after his visit to Pearl Harbor a week or two after December 7, 1941.

\section{REPORT BY THE SECRETARY OF THE NAVY TO THE PRESIDENT}

The Japanese air attack on the Island of Oahu on December 7th was a complete surprise to both the Army and the Navy. Its initial success, which included almost all the damage done, was due to a lack of a state of readiness against such an air attack, by both branches of the service. This statement was made by me to both General Short and Admiral Kimmel, and both agreed that it was entirely true. Neither Army or Navy Commandants in Oahu regarded such an attack as at all likely, because of the danger which such a carrier-borne attack would confront in view of the preponderance of the American Naval strength in Hawaiian waters. While the likelihood of an attack without warning by Japan was in the minds of both General Short and Admiral Kimmel, both felt certain that such an attack would take place nearer Japan's base of operations, that is, in the Far East.

So, both commanders evaluated $\mathrm{P}$ to be so small, that they neglected their duty of keeping the American forses at Pearl Harbor in a state of readiness against such an air attack.

-(YC) - But what corrresponds to Garabed's lust for backgammon triumphs? Without an analogous element the allegory is not complete.

- The chapter JAPAN where Churchill prepares the stage for the next chapter, PEARL HARBOUR! points at that necessarty element. Let me reproduce some citations from JAPAN:

1. My deepest fear was that the Japanese would attack us or the Dutch, and that constitutional difficulties would prevent the United States from declaring war. 
2. We know that all the Great Americans round the President and in his confidence felt as acutely as I did the awful danger that Japan would attack British or Dutch possessions in the Far East and would carefully avoid the United States, and that in consequence Congress would not sanction an American declaration of war.

3. A declaration of war by Japan could not be reconciled with reason.... Maddness is however an affliction which in war carries in it the advantage of surprise.

By the way, Churchill's declaration, that the Japanese gave the order to attack Pearl Harbor in a state of madness amounts to rather low estimate of the value of the probability $\mathrm{P}$ defined above. Do you know anything about the historical event

[D8-1] = on Dec. 8 Britain declared war on Japan,

that occurred a few hours before US Congress declaration of war on Japan?

-(YC) -No, I know absolutely nothing about [D8-1]. My knowledge of Churchill's book [2] is probably unsatisfactory

- Right, other popular books seem not to give any information on [D8-1] at all. Here is the text of Britain's war declaration on Japan from PEARL HARBOUR! chapter:

As Eden had already started on his journey to Moscow and I was in charge of the Foreign Office I sent the following letter to the Japanese Ambassador

Foreign Office, December 8th

Sir, On the evening of December $7^{\text {th }}$ His Majesty' Government in the United Kingdom learned that Japanese forces without previous warning either in the form of declaration of war or of ultimatum with a conditional declaration of war had attempted a landing on the coast of Malaya and bombed Singapore and Hong Kong.

In view of these wanton acts of unprovoked aggression $\quad[\ldots .$.$] His majesty's Ambassador$ at

Tokyo has been instructed to inform the Imperial Japanese Government in the name of His Majesty's Government in the United Kingdom that a state of war exists between our two countries [....] Winston S. Churchil.

Parliament met at 3 p.m., and in spite of the shortness of notice the House was full. Under the British constitution the Crown declares war on the advice of Ministers, and Parliament is confrunted with the fact. We were therefore able to be better than our word to the United States, and actually declared war upon Japan before Congress could act. The Royal Netherlands Government had also made their declaration.

-(YC) -Can you comment Churchill's statement about his word to the United States?

- In the chapter PEARL HARBOUR! Churchill describes the striking circumstances of his telephone interchange with Roosevelt in the evening of December 7 : Mr. President, what's this about Japan?'[Churchill has just heard few sentences by radio news, spoken regarding an attack by the Japanese on Hawaii] "It's quite true" he replied. "They have attacked us at Pearl Harbour. We are all in the same boat now." That was enough for immediate (within few hours) dispatch of the letter to the Japanese Ambassador containing war declaration. In the same passage Churchill explains:

on November $11 \mathrm{I}$ had said [promised to Rosevelt] that if Japan attacked the United States a British declaration of war would follow "within the hour".

-(YC) -Should one conclude that Churchill declared war on Japan acting on a signal from Roosevelt?

- Churchill leaves no doubt about it. After hearing "we are all in the same boat now" from Roosevelt, Churchill's reaction was: At this very moment I knew the United States was in the war, up to the neck and in to the death.... Hitler's fate was sealed...Mussolini's fate was sealed (from PEARL

HARBOUR!).

$-(\mathrm{YC})-\mathrm{Was}$

[D7] $=$ on Dec. 7 the Japanese plane attacked Pearl

Harbor not enough to trigger the event 
[D8-2] = on Dec. 8, US Congress declaration of war on Japan?

- Probably Roosevelt suspected, that "skeptics" in the Congress would share the conviction of

General Short and Admiral Kimmel that the probability P of the event [D7] was too low:

The urgent realization of [D8-1] indicates that [D8-1] was probably necessary to make the

"skeptics" to vote for [D8-2]. For the "non-skeptics", voting for [D8-2] was made easier since formally, [D7] alone could not compel Hitler to immediately enter the war against USA on the side of Japan (see the "Logical chain" below) . So [D8-1] in conjunction with Roosevelt's Infamy Day address was calculated to produce an unuanimous vote.

-(YC) -Churchills profecy about Hitler's and Mussolini's fate are surprising: [D8-2] by no means implied that the Congress would declare war on Germany.

- There are official prophecies by Churchill on war on Germany, for instance in his letter to the King of December 8, 1941 (reproduced in PEARL HARBOUR!):

I am expecting that Germany and Italy will both declare war on the United States, as they have bound themselves by treaty to do so. I shall defer proposing my visit to President until this situation is more clear. Churchill was confident and he was right: on December 11 followed the event

[D11] = Hitler declares of war on the USA.

-(YC) - But as I understand WWII history, Hitler wished to avoid war with America at any cost.

- You are right, the Index in Churchill's book contains a volumous entry Hitler fearful of war with America. In December 1941, Germany could hope for victory in the European war that started in 1939 only by avoiding war with the United States. Hitler could avoid or delay declaration of war on USA by simply accepting that [D7] as valid: Germany was not bound by the axis treaty to enter the war on the side of Japan if the war was started by Japan, and was bound to do so if Japan was the victim of an aattack. We came to the following Logical chain:

Roosevelt declared [D7] as valid and the Congress started war on Japan; yet

if [D7] was indeed valid, then Hitler could avoid declaration of war on

America; but although fearful of war with America, Hitler declared war on US.

Therefore [D7] is invalid.

-(YC) - How a historical event can be "invalid"?

- "[D7] invalid" means that [D7] was an invention of American war propaganda. But

"[D7] invalid" enabled Roosevelt to reach his main purpose, i.e. to bring USA in war with

Germany.

-(YC) - So you state, that the sequence [D7], [D8-2] and [D11] is internally contradictory. But if [D7] was merely a propaganda, then what caused the sinking of the US ships? Ships are not words: the battleship Arizona remains under water even today.

- Can you answer the question: why Arizona was left under water at the moment, when US started an enormous naval construction program to fight the war on two oceans? Within "[D7] invalid", Arizona was kept under water in order to hide the real course of her fate, that is an internal explosure. But this is only a conjecture which needs a proof: Arizona's question remains unsolved. With it under question remains the conclusion about invalidity of [D7]. Now we can only state that [D7] is invalid with high probability.

\section{Subsets of the sextet}

One of the questions discussed in the chapter CLOSER CONTACTS WITH RUSSIA is the question of declaration of war by Britain on Finland, Roumania and Hungary. The latter three countries together with Hitler attacked USSR in summer 1941, but Stalin's repeated addresses to Churchil demanding action from Britain for some time produced no

result: Prime Minister to Premier Stalin, 4 Nov. 41:

[...] Will you however consider whether it is really good business that Great Britain should declare war on Finland, Hungary and Romania at this moment? [...] My judgement is against it 
because, first, Finland has many friends in the United States. Secondly, Roumania and Hungary are full of our friends [...] A British declaration of war would only freeze them all and make it look as if Hitler were the head of a grand European alliance. (From CONTACTS.).

In a few days a change in Churchill's attitude followed. In his telegram to Stalin of November 21 ,

1941 reproduced in CONTACTS wrote Churchill:

About Finland. I was quite ready to advise Cabinet to declare war upon Finland when I sent you my telegram of September 4. Later information has made me think [about a delay]. However, if they do not stop [fighting ] in the next fortnight and you still wish us to declare war on them, we will certainly do so. (A fortnight (14 days) after Nov. 21 is Dec.5.)

Churchill's telegram to Foreign Secretary and to Mannerheim (from

CONTACTS): Prime Minister to Foreign Secretary, 28 Nov. 41

You seem to be taking it for granted that war will be declared on all three powers (Finland, Roumania and Hungary) on December 3. I do not wish this decision to be taken till we know what Finland will do. Moreover, the $3^{\text {rd }}$ is too soon. The $5^{\text {th }}$ is the fortnight after my telegram to Stalin. I am only to-night sending my telegram to Mannerheim.

Prime Minister to Field-Marshal Mannerheim , 29 Nov. 41:

"I am deeply grieved at what I see coming, namely, that we shall be forced in a few days out of loyalty to our ally Russia to declare war upon Finland. [...] I wish I could convince your Excellency

that we are going to beat the Nazis. I feel far more confident than in 1917 or 1918".

1917 and 1918 were the two years in which US fought against Germany in the First World War. Hence the phrase Ifeel far more confident than in 1917 or 1918 can be interpreted that Churchill was confident in near entrance of US into the war against Germany. In other words, on Nov 29, 1941 Churchill was sure in [D11]. However, [D11] was impossible without [D8-2], while by Rosevelt version, [D8-2] was in its turn impossible without [D7]. It follows, that on Nov. 29, 1941 Churchill knew that the Japanese carrier fleet was on its way to attack Pearl Harbor - an obvious contradiction with the presumption of a complete surprise attack.

If [D7] is accepted as invalid, the purpose of Chirchill's actions [D5] and [D8-1] appears as follows :

1. [D5] created a precedent for the principle: the attacker of an ally should be attacked.

2. [D8-1] presented Japan as an attacker of Britain. Due to Churchill's control of the situation the precedent turned to be rather fresh (telegram to Foreign Secretary of 28 Nov.);

Let us consider the triad [D6], [D7], [D8-2]. On $6^{\text {th }}$ December, 1941 the Red Army troops from the Soviet Far East started the successful Moscow winter offensive. Due to geographical distance, the order to move the troops to Moscow front was probably issued at least a fortnight before Dec. 6, i.e. before November 21. Did Stalin take a risk that Japan would attack the unprotected Soviet Far East? On Dec. 8, USA declared war on Japan and thus excluded any possibility of that attack. One concludes, that well before Dec. 6 Roosevelt has guaranteed [D8-2] to Stalin. But Roosevelt could not guarantee [D7]: that event turned to be a complete surprise to both the [US] Army and the Navy. No contradiction remains if [D7] is accepted as invalid.

\section{The distance factor}

The chapter PEARL HARBOUR! invites reader's attention to the events that unfolded in the Philippines on Dec. 8. We cite: "At 3 a.m. on December 8 Admiral Hart intercepted a message giving staggering news of the attack on Pearl Harbor. He at once warned all concerned that hostilities had begun, without waiting for confirmation from Washington. At dawn the Japanese dive--bombers struck, and throughout the ensuing days the air attacks continued on ever-increasing scale. On the 10th the naval base at Cavite was completely destroyed by fire, and on the same day the Japanese made their first landing in the north of Luzon. Disasters mounted swiftly. Most of the American air forces were destroyed in battle or on the ground, and by December 20 the remnants had been withdrawn to Port Darwin, in Australia." 
According to Roosevelt version of the events, all this happened in the period, when all the six newest and largest carriers of the Japanese fleet were many thousands miles away, nearer to Pearl Harbor than to the South China Sea, and hence they could not participate in the battle. If so, then where from did the Japanese dive-bombers operate?

Churchill abstained from mentioning, from which bases came the Japanese dive-bombers, but the historian S.E. Morison says bluntly in (Morrison 1972): from Formosa. That island contained Japanese airfields nearest to Manila; yet they were at least $800 \mathrm{~km}$. $=500$ miles from the scene. A question arises: what was the range of action of the dive-bombers in 1941 ?

S. E. Morison in (Morrison 1972) states that the Japanese fleet that attacked Pearl Harbor was stationed at the distance of 220 miles from its target. In order to minimize the danger of a counterstrike from the island air bases, the Japanese had to choose the maximal possible distance, from which their air strike could still be effective. So the real effective range in question hardly exceeds 250 miles.

The chapter CRETE: THE BATTLE describes the British disaster of May 1941 at Crete, inflicted mainly by the German air force. Writes Churchill (Churchill 1949):

"As the agony in Crete approached its climax, I telegraphed to President Roosevelt: "Battle in Crete is severe, because, having no airfields within effective range, we can not bring air force into action either to aid the defense or protect our patrolling squadrons. Two of our cruiser and two destroyers were sunk today.'" A glance at the map of Mediterranean shows, that the African coast is about 250-300 miles away from Crete, where British certainly possessed many airfields

(Tobruk). That distance made British air force participation at Crete impossible. Yet under Roosevelt version, the distances of 500 miles did not stop the Japanese planes!

So the Japanese victories in South China Sea can not be attributed to planes operating from the shore airfields. The Japanese victories could convince Hitler of the presence of the Japanese carriers in the South China Sea, rather than near Pearl Harbor. In fact after [D10] Hitler was left with no other choice but to ignore [D7] and undertake [D11].

\section{Within [D7] observations}

If the event [D7 ] is considered separately from the other events of the sextet, then a number of

observations internal for [D7 ] still confirm, that the probability $\mathrm{P}$ of [D7 ] is rather low (equivalently, the value of the event "[D7] invalid" is rather high ). We present a short list of such observations .

1. From (Morrison 1972): the Army was "responsible for five or six mobile search radar stations, spotted around the coast of Oahu". Radar had saved England during the German air blitz of 1940, and by end 1941 they were rather widespread. How then could Japanese side plan a surprise attack? In case US land--based air force was appropriately warned by the radars, the Japanese plan was doomed to bring a disaster to the attacking fleet.

2. Speaking on radars, (Morrison 1972) mentions that following a special order, on the morning of Dec. 7 all radars had been switched off a few minutes before the hour X. However, one of them failed to comply with that order immediately: that radar saw the approaching planes. A "green lieutenant" on duty, instead of sending alert orders "listened in a bored manner and told them [to subordinate operators] to "forget it'"'. Could the Japanese plan this outcome? In the framework of "[D7] invalid" version, the lieutenant simply recognized friendly planes.

3. During the raid, many US ships suffered interior explosions. (Morrison 1972) explains this, stating that the dive - bombers dropped "not only conventional bombs but converted 16 - inch armor - piercing shells which penetrated the deck and exploded below". The armor - piercing effect of a shell depends on its speed: the necessary speed exceeds many times the speed that can be reached by a shell dropped from an airplane. So the cited explanation is essentially nonsense. Within "[D7] invalid" version, the internal explosions could be produced by charges placed beforehand.

4. Describing 8 December daybreak at Pearl Harbor, writes (Churchill 1949): "The atmosphere was one of tormenting uncertainty. Nobody knew where the Japanese task force was; the one radar 
fix on it was interpreted 180 degrees wrong, so many a ship and most of the flyable planes were sent scurrying southward." The "[D7] invalid" version again explains: the official version placed nonexistent Japanese ships in the North, so to save the official version, the Roosevelt fifth columnists were ready to send the planes in any direction except North.

5. Could planes from the US carriers reach Pearl Harbor at the moment of the attack, i.e. were the US carriers located near enough? OCEAN: "Saddest of all accidents was the shooting down at night of four dive--bombers from the carrier Enterprise. These had landed at Ford Island during the morning lull [on Deember 7] and were then sent out to search for the enemy. When they returned after nightfall with running lights on, an antiaircraft gunner, who failed to get the word because the air base communications had been ruptured, opened fire..." . Within "[D7] invalid" version, the purpose of this story could be to explain the real losses among the planes from the US carriers that imitated the Japanese air attack.

We finish with the remark, that the list of similar observations can be made much longer; some of them have been presented in (Ambartzunian 2009: 8-16). By the rule of multiplication of probabilities, the complete list may essentially diminish the already low estimate of the probability $\mathrm{P}$ in question. 